Western University

Scholarship@Western

Chemistry Publications

Chemistry Department

$11-15-2008$

Synthesis and first X-ray structures of cobalt(II) and cobalt(III) complexes bearing 2,4-dioxoalkanoic acid dialkylamide ligands

Brian Pagenkopf

University of Western Ontario, bpagenko@uwo.ca

Jian Wang

Nicholas A. Morra

Hongda Zhao

Vincent Lynch

See next page for additional authors

Follow this and additional works at: https://ir.lib.uwo.ca/chempub

Part of the Chemistry Commons

Citation of this paper:

Pagenkopf, Brian; Wang, Jian; Morra, Nicholas A.; Zhao, Hongda; Lynch, Vincent; McDonald, Robert; and Reichwein, John F., "Synthesis and first X-ray structures of cobalt(II) and cobalt(III) complexes bearing 2,4-dioxo-alkanoic acid dialkylamide ligands" (2008). Chemistry Publications. 55.

https://ir.lib.uwo.ca/chempub/55 
Authors

Brian Pagenkopf, Jian Wang, Nicholas A. Morra, Hongda Zhao, Vincent Lynch, Robert McDonald, and John F. Reichwein 


\title{
Synthesis and First X-ray Structures of Cobalt(II) and Cobalt(III) Complexes Bearing 2,4- dioxo-alkanoic Acid Dialkylamide Ligands
}

\author{
Jian Wang, Nicholas A. Morra, Hongda Zhao, Jeffrey S. T. \\ Gorman, Vincent Lynch, Robert McDonald, John F. \\ Reichwein and Brian L. Pagenkopf*
}

\begin{abstract}
The aerobic oxidation of 5-hydroxy pentenes to trans-tetrahydrofurans (THFs), the Mukaiyama oxidation, has in recent years emerged as a powerful tool in synthetic chemistry. In this report we describe the first crystal structures of 2,4-dioxo-alkanoic acid dialkylamide complexes for both $\mathrm{Co}(\mathrm{II})$ and $\mathrm{Co}(\mathrm{III})$ salts. The $\mathrm{Co}$ (II) structures show an unprecedented arrangement of atoms, with a central $\mathrm{Co}(\mathrm{II})\left(\mathrm{H}_{2} \mathrm{O}\right)_{6}$ flanked by two $\mathrm{Co}(\mathrm{II})$ atoms each coordinated with three anionic chelating ligands. The dimeric $\mathrm{Co}(\mathrm{III})$ structures show two anionic chelating ligands and bridging hydroxyl groups.
\end{abstract}

Key words: aerobic oxidation, THF, cobalt, X-ray crystallography, oxidation, coordination.

RECEIVED DATE (automatically inserted by publisher).

J. Wang, N. A. Morra and B. L. Pagenkopf. ${ }^{1}$ Department of Chemistry, The University of Western Ontario, London, ON N6A 5B7

H. Zhao, J. S. T. Gorman, V. Lynch, ${ }^{2}$ and J. F. Reichwein. Department of Chemistry, The University of Texas at Austin, Austin, TX 78712

R. McDonald. ${ }^{3}$ Chemistry Department, University of Alberta, Edmonton, Alberta, T6G 2G2

${ }^{1}$ Corresponding author: Brian L. Pagenkopf (email: bpagenko@uwo.ca).

${ }^{2}$ Corresponding author for questions concerning structures 3e and 7: V. Lynch (email: vmlynch@mail.utexas.edu).

${ }^{3}$ Corresponding author for questions concerning structure 9: R. McDonald (email:

Bob.McDonald@ualberta.ca).

\section{Introduction}

Co(III) complexes of 2,4-dioxo-alkanoic acid dialkylamides are useful catalysts for the aerobic oxidation of olefins to peroxides or alcohols $(1,2,3,4,5)$, and for the oxidative cyclization of 5-hydroxy pentenes to tetrahydrofurans (THFs) (6). In recent years the stereoselective aerobic oxidation of 5-hydroxy pentenes to
trans-THFs (henceforth the Mukiayama oxidation, Scheme 1) has emerged as a powerful tool in organic synthesis, and has been strategically employed in the total synthesis of natural products by the groups of Wang and Shi (7), Takahashi and Nakata (8), Evans (9), and Pagenkopf (10). Surprisingly, despite the obvious synthetic importance of these catalysts there is little structural information available on transition metal 2,4-dioxo amide complexes, and to the best of our knowledge no X-ray structures of these species have been reported. In this paper we describe crystal structures of two $\mathrm{Co}$ (II) complexes and one $\mathrm{Co}(\mathrm{III})$ complex.

Scheme 1. Representative Mukaiyama oxidation

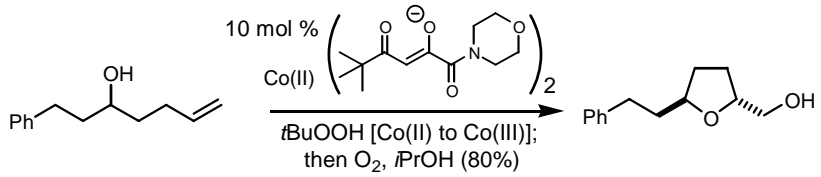

\section{Experimental}

General procedure for ligands 2

To a cooled $\left(0{ }^{\circ} \mathrm{C}\right)$ solution of dialkylamine $(10 \mathrm{mmol})$ and $\mathrm{Et}_{3} \mathrm{~N}(10 \mathrm{mmol})$ in $\mathrm{CH}_{2} \mathrm{Cl}_{2}(20 \mathrm{~mL})$ was added ethyl oxalyl chloride $(10 \mathrm{mmol})$. After stirring at room temperature for $16 \mathrm{~h}$, the reaction mixture was washed with $1 \mathrm{M} \mathrm{HCl}(2 \mathrm{x})$, sat. $\mathrm{NaHCO}_{3}$, brine and dried $\left(\mathrm{MgSO}_{4}\right)$. Concentration in vacuo gave $\mathbf{1}$ as a white solid or colorless 
oil in quantitative yield which was used without further purification.

A solution of $t$-BuOK (23 g, $205 \mathrm{mmol} 2.1 \mathrm{eq})$ in THF $(180 \mathrm{~mL})$ was added via cannula to a solution of pinacolone (12 mL, $96 \mathrm{mmol}, 1.0 \mathrm{eq})$ and amide 1a (18 g, $96 \mathrm{mmol}, 1.0 \mathrm{eq})$ in THF ( $40 \mathrm{~mL})$ over $40 \mathrm{~min}$ at rt. After 3 h, AcOH (20 mL, $350 \mathrm{mmol}, 3.6 \mathrm{eq})$ was added over $5 \mathrm{~min}$ and the resulting heterogeneous mixture was filtered and the solids were washed with $\mathrm{CH}_{2} \mathrm{Cl}_{2}$. The filtrate was washed with $\mathrm{NaHCO}_{3}$ and brine, dried, filtered and concentrated. Purification of the resulting oil by flash chromatography $\left(\mathrm{SiO}_{2}, 50 \%\right.$ EtOAc/hexanes) provided the title compound as a slightly yellow solid (18.1 g, 78\%).

To a solution of $2(7.0 \mathrm{mmol})$ in hexanes or benzene (3a) was added $\mathrm{Co}(\mathrm{II})(2 \text {-ethyl-hexanoate })_{2}(3.5 \mathrm{mmol})$ solution in mineral spirits. The reaction mixture was stirred at room temperature for 8 hours and hexane (ca. $70 \mathrm{~mL}$ ) was added to induce precipitation. The solids were separated by centrifugation or filtration, and washed with hexane.

Full characterization of $\mathrm{Co}(\mathrm{II})$ complexes by NMR was not possible because the salts are paramagnetic. Combustion analysis is significantly out of range because the number of water molecules within the powder varies, and drying generally led to decomposition. Attempts to record discrete melting points also led to decomposition. Several of these complexes are known compounds, including 3a, 3b, and 3c (3a,11).

3a: pink amorphous solids; MS (CI) $m / z 540[\mathrm{M}+\mathrm{H}]^{+}$, $242[\text { ligand }+\mathrm{H}]^{+}$.

Table 1. Crystallographic data collection parameters for 7, 3e, 9.

\begin{tabular}{|c|c|c|c|}
\hline Complex & $3 \mathbf{e}$ & 7 & 9 \\
\hline Chemical formula & $\mathrm{C}_{204} \mathrm{H}_{198} \mathrm{Co}_{3} \mathrm{~N}_{6} \mathrm{O}_{21}$ & $\mathrm{C}_{126} \mathrm{H}_{144} \mathrm{Co}_{3} \mathrm{~N}_{6} \mathrm{O}_{24}$ & $\mathrm{C}_{98.5} \mathrm{H}_{110} \mathrm{Co}_{2} \mathrm{~N}_{4} \mathrm{O}_{14}$ \\
\hline Formula weight & 3246.58 & 2303.32 & 1691.77 \\
\hline Crystal dimensions $\left(\mathrm{mm}^{3}\right)$ & $0.32 \times 0.26 \times 0.15$ & $0.50 \times 0.14 \times 0.11$ & $0.53 \times 0.27 \times 0.15$ \\
\hline Crystal system & triclinic & monoclinic & monoclinic \\
\hline Space group & $\overline{P 1}$ & $P 21 / n$ & $I a$ \\
\hline $\mathrm{Z}$ & 2 & 2 & 4 \\
\hline$a(\AA)$ & $17.9663(1)$ & $16.5500(5)$ & $24.6233(16)$ \\
\hline$b(\AA)$ & $23.9160(2)$ & $20.8953(6)$ & $13.1161(9)$ \\
\hline$c(\AA)$ & $24.1629(2)$ & $19.1655(6)$ & $29.4833(19)$ \\
\hline$\alpha\left(^{\circ}\right)$ & $67.360(1)$ & 90 & 90 \\
\hline$\beta\left(^{\circ}\right)$ & $85.866(1)$ & $98.326(2)$ & $98.3545(10)$ \\
\hline$\gamma\left({ }^{\circ}\right)$ & $84.983(1)$ & 90 & 90 \\
\hline Volume $\left(\AA^{3}\right)$ & $9537.27(12)$ & $6557.9(3)$ & $9420.9(11)$ \\
\hline$D_{\text {calcd. }}\left(\mathrm{mg} \mathrm{cm}^{-3}\right)$ & 1.181 & 1.275 & 1.193 \\
\hline$T(\mathrm{~K})$ & $153(2)$ & $153(2)$ & $193(2)$ \\
\hline Radiation & Mo K $\alpha(0.71073)$ & Mo $\mathrm{K} \alpha(0.71073)$ & Mo $\mathrm{K} \alpha(0.71073)$ \\
\hline$\mu\left(\mathrm{mm}^{-1}\right)$ & 0.324 & 0.448 & 0.414 \\
\hline Total reflections collected & 74396 & 16105 & 36466 \\
\hline Total unique reflections & $43644[\mathrm{R}($ int $)=0.0439]$ & $8560[\mathrm{R}(\mathrm{int})=0.0606]$ & $19200[\mathrm{R}(\mathrm{int})=0.0365]$ \\
\hline Observed reflections $[I>2 \sigma(I)]$ & 16105 & 74396 & 15217 \\
\hline $2 \theta_{\max }\left({ }^{\circ}\right)$ & 54.98 & 45.00 & 52.78 \\
\hline Goodness-of-fit on $F^{2}$ & 2.423 & 1.165 & 0.987 \\
\hline$R_{1}[I>2 \sigma(\mathrm{I})]$ & 0.0847 & 0.0602 & 0.0504 \\
\hline$w R_{2}$ (all data) & 0.1576 & 0.1373 & 0.1290 \\
\hline Largest diff. Peak and hole $\left(\mathrm{e} \AA^{-3}\right)$ & 1.103 and -0.503 & 0.486 and -0.320 & 0.557 and -0.316 \\
\hline
\end{tabular}

3b: pink amorphous solids; MS (CI) $m / z 536[\mathrm{M}+\mathrm{H}]^{+}$, 240 [ligand $+\mathrm{H}]^{+}$.

3c: pink amorphous solids; MS (CI) $m / z 512[\mathrm{M}+\mathrm{H}]^{+}$, 228 [ligand $+\mathrm{H}]^{+}$.

3d: brownish peach colored amorphous solids; MS (CI) $m / z 760[\mathrm{M}+\mathrm{H}]^{+}$.

4: pink amorphous solids, MS (CI) $m / z 676[\mathrm{M}+\mathrm{H}]^{+}$.

5: redish brown brittle foam, MS (CI) $m / z 732[\mathrm{M}+\mathrm{H}]^{+}$.

7: red crystals; MS (CI) $m / z 732[\mathrm{M}+\mathrm{H}]^{+}$.

3e: red crystals; MS (CI) $m / z 1064[\mathrm{M}+\mathrm{H}]^{+}$.

To a mixture of $\mathbf{3 d}(0.76 \mathrm{~g}, 1 \mathrm{mmol}, 1.0$ equiv) in acetone (20 mL) was added $30 \% \mathrm{w} / \mathrm{w} \mathrm{H}_{2} \mathrm{O}_{2}(1.2 \mathrm{~mL}, 10 \mathrm{mmol}, 10$ equiv) at room temperature. After $15 \mathrm{~h}$ the solution was concentrated under reduced pressure. TLC showed the residue showed numerous spots. Flash chromatography over silica gel (25\% EtOAc/hexanes) allowed separation of at least six distinct bands, one of which $\left(\mathrm{R}_{\mathrm{f}}=0.25,40 \%\right.$ EtOAc/hexanes) provided material that eventually crystallized. The crystal for X-ray analysis was grown from a vapor diffusion chamber containing EtOAc, toluene and hexanes: ${ }^{1} \mathrm{H}$ NMR $\left(600 \mathrm{MHz}, \mathrm{C}_{6} \mathrm{D}_{6}\right) \delta 7.43(\mathrm{~d}, J=7.3 \mathrm{~Hz}$, 4H), 7.24-7.20 (m, 8H), 7.15-7.08 (m, 8H), $7.00(\mathrm{~d}, J=$ $7.1 \mathrm{~Hz}, 4 \mathrm{H}), 6.88-6.81(\mathrm{~m}, 10 \mathrm{H}), 6.75(\mathrm{t}, J=7.50,4 \mathrm{H})$, $6.53(\mathrm{~s}, 2 \mathrm{H}), 6.34(\mathrm{~s}, 2 \mathrm{H}), 6.26(\mathrm{t}, J=7.3 \mathrm{~Hz}, 2 \mathrm{H}), 5.58(\mathrm{~d}, J$ $=14.5 \mathrm{~Hz}, 2 \mathrm{H}), 5.29(\mathrm{~d}, J=15.4 \mathrm{~Hz}, 2 \mathrm{H}), 5.20(\mathrm{~d}, J=14.1$ $\mathrm{Hz}, 2 \mathrm{H}), 4.28$ (d, $J=16.8 \mathrm{~Hz}, 2 \mathrm{H}), 3.44-3.38(\mathrm{~m}, 6 \mathrm{H}), 3.02$ $(\mathrm{d}, J=16.5 \mathrm{~Hz}, 2 \mathrm{H}), 1.26(\mathrm{~s}, 18 \mathrm{H}), 1.01(\mathrm{~s}, 18 \mathrm{H}),-3.39$ (s, 1H), -3.72 (s, 1H); ${ }^{59} \mathrm{Co}$ NMR (144 MHz, C $\left.6 \mathrm{D}_{6}\right) \delta 13364$ (brs); combustion (calculated C 67.28, H 6.31, N 3.62; found C 68.03, H 6.36, N 3.62).
Synthesis and characterization of 9 


\section{Results and Discussion}

\section{Cobalt(II) Structures}

Our initial efforts to employ the Mukaiyama oxidation in synthesis were complicated by fickle oxidation results as a consequence of inconsistent purity of the Co(II) complex. The first reports on Co(II) 2,4-dioxo-alkanoic acid amide complexes utilized $\mathrm{CoCl}_{2}$ under aqueous alkaline conditions, but we found that such conditions caused decomposition of the morpholine amide 2a (Scheme 2). The result was that the preparation of catalyst 3a under the aqueous conditions provided a highly contaminated amorphous brown solid, and attempts at purification proved fruitless. However, these difficulties were overcome by complexation under neutral conditions in organic solvent. When a solution of the free ligand $2 \mathbf{a}$ in benzene was treated with 0.5 equivalents of $\mathrm{Co}(\mathrm{II})(2 \text {-ethyl hexanoate })_{2}$, the initial dark blue color quickly dissipated, and the resulting red solution was treated with hexane to precipitate the complex $\mathbf{3 a}$.

Scheme 2. Synthesis of Co(II) complexes

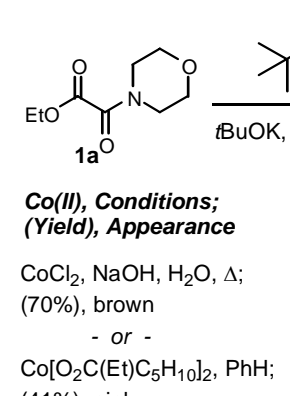

(41\%), pink

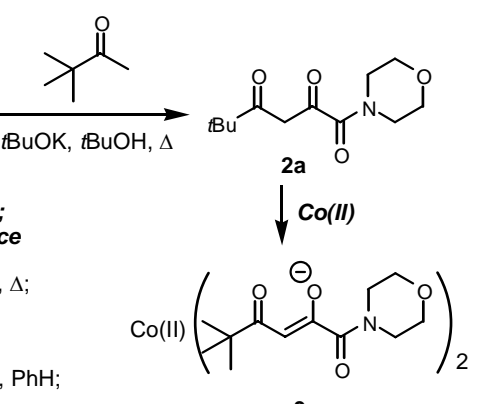

$3 \mathbf{a}$
This modified procedure proved effective for the preparation of a variety of 2,4-dioxo amide complexes, and these results are summarized in Table 2. Replacement of the morpholine with piperidine (3b), diethylamine (3c) or dibenzyl amine (3d) gave complexes as microcrystalline pink powders unsuitable for single crystal X-ray analysis. Of these, the dibenzyl amide 3d displayed the most promising crystalline character, and in entries $5-7$ the dibenzyl amide portion of the ligand was conserved while substitutions were made in place of the tert-butyl group. The methyl (4), isopropyl (5) and phenyl (6) analogs of 3d were each prepared successfully, but they too failed to give crystals suitable for X-ray analysis.

A more substantial change was made by installing a methyl group at $\mathrm{C}(3)$, and gratifyingly, the complex 7 was obtained as red crystals, and the unusual X-ray structure of 7 is shown in Figure 1 (12). Selected bond lengths and angles are reported in Table 3 . There are three cobalt atoms present in the unit cell, each separated by $4.870 \AA$. The two outer cobalt atoms are each surrounded by three dioxoamide ligands, and their negative charge is balanced by a central $\mathrm{Co}(\mathrm{II})\left(\mathrm{H}_{2} \mathrm{O}\right)_{6}$. The dihedral angle between the amide carbonyl and the acac-like plane is $118(1)^{\circ}$, which might be expected in order to minimize $A(1,3)$ strain with the $\mathrm{C}(3)$ methyl group. The unfavorable $\mathrm{A}(1,3)$ interaction was also evident in the ${ }^{1} \mathrm{H}$ NMR spectra of the metal-free ligand 8, which in $\mathrm{CDCl}_{3}$ existed as a 1:1 ratio of both the keto and enol forms (Scheme 3). In contrast, the preceding ligands existed primarily in the enol form. The distinctly different structure and behavior of ligand 8 compared to the others caused concern that the structure of $\mathbf{7}$ may be unique and not representative of the series.

Table 2. Preparation of Co(II) complexes ${ }^{a}$

\begin{tabular}{|c|c|c|c|}
\hline Entry & Co(II) Complex & $\#$ & Yield $^{b}$ \\
\hline 1 & & 3a & $99 \%$ \\
\hline 2 & י & $3 \mathbf{b}$ & $75 \%$ \\
\hline 3 & & 3c & $59 \%$ \\
\hline 4 & & 3d & $59 \%$ \\
\hline 5 & & 4 & $99 \%^{c}$ \\
\hline 6 & $\mathrm{Co}(\|)$ & 5 & $27 \%$ \\
\hline 7 & & 6 & $45 \%$ \\
\hline 8 & & 7 & $76 \%$ \\
\hline 9 & & $3 \mathbf{e}$ & $23 \%$ \\
\hline
\end{tabular}

${ }^{a}$ the compounds shown are representative of the metal to ligand stoichiometry only, and are not meant to imply structure. ${ }^{b}$ unoptimized yields of complexation ${ }^{c}$ poor solubility.

Scheme 3. Equilibrium disfavors the enol form

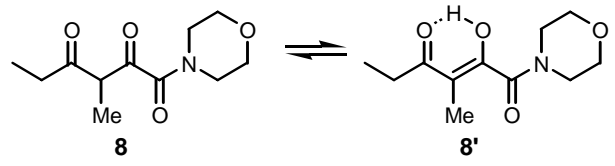

To address concerns that the $\mathrm{C}(3)$ methyl may have led to a structural anomaly, additional complexes more closely resembling 3d were prepared. Of these, the bi-phenyl analog 3e (Table 2, entry 9) formed crystals suitable for Xray analysis (Figure 2). Importantly, the major features of the two structures are conserved, including the arrangement of the three cobalt atoms and the angle of the amide. A 
minor difference is that central cobalt in $\mathbf{3 e}$ is surrounded by only three water molecules, with the coordination sphere being fulfilled by dative bonding from a neighboring ligand. The distance between $\mathrm{Co}(1)$ and $\mathrm{Co}(2)$ was found to be $4.980 \AA, \operatorname{Co}(2)$ and $\operatorname{Co}(3)$ are separated by $2.926 \AA$. Bond lengths and angles of significance are reported in Table 4.

Table 3. Selected bond lengths $[\AA]$ and angles $\left[{ }^{\circ}\right]$ for $\mathbf{7}$.

\begin{tabular}{llll}
\hline $\mathrm{C}(45)-\mathrm{C}(46)$ & $1.450(7)$ & $\mathrm{C}(49)-\mathrm{O}(9)$ & $1.236(6)$ \\
$\mathrm{C}(45)-\mathrm{O}(7)$ & $1.246(6)$ & $\mathrm{C}(49)-\mathrm{N}(2)$ & $1.339(6)$ \\
$\mathrm{C}(46)-\mathrm{C}(48)$ & $1.367(7)$ & $\mathrm{Co}(1)-\mathrm{O}(7)$ & $2.021(4)$ \\
$\mathrm{C}(48)-\mathrm{C}(49)$ & $1.535(7)$ & $\mathrm{Co}(1)-\mathrm{O}(8)$ & $2.075(3)$ \\
$\mathrm{C}(48)-\mathrm{O}(8)$ & $1.287(5)$ & $\mathrm{N}(2)-\mathrm{C}(57)$ & $1.471(6)$ \\
$\mathrm{O}(7)-\mathrm{C}(45)-\mathrm{C}(46)$ & $124.3(5)$ & $\mathrm{C}(45)-\mathrm{O}(7)-\mathrm{Co}(1)$ & $132.2(3)$ \\
$\mathrm{C}(48)-\mathrm{C}(46)-\mathrm{C}(45)$ & $121.4(5)$ & $\mathrm{C}(48)-\mathrm{O}(8)-\mathrm{Co}(1)$ & $125.9(3)$ \\
$\mathrm{O}(8)-\mathrm{C}(48)-\mathrm{C}(46)$ & $129.2(4)$ & $\mathrm{O}(7)-\mathrm{Co}(1)-\mathrm{O}(8)$ & $85.73(13)$ \\
\hline
\end{tabular}

A

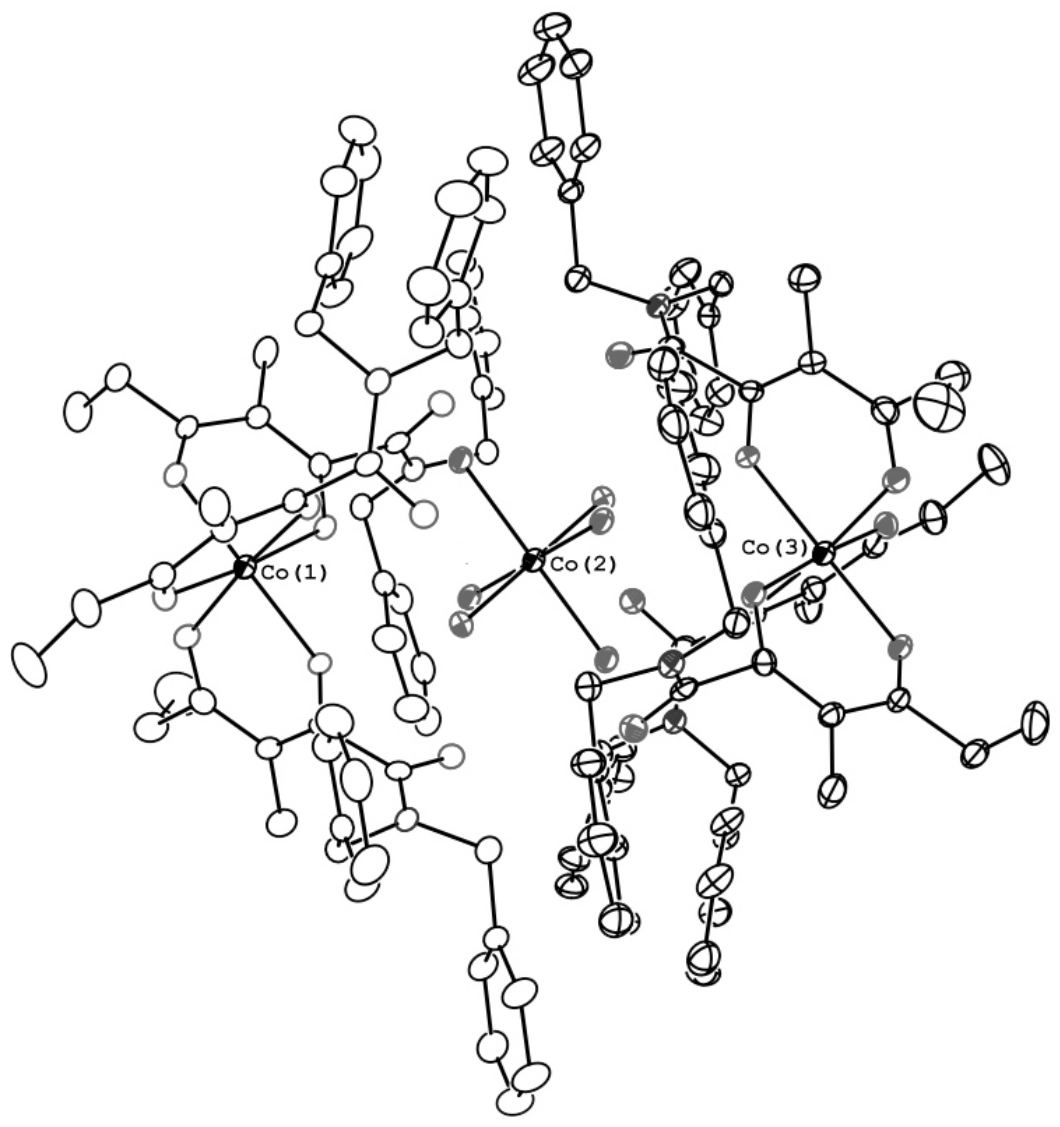

B
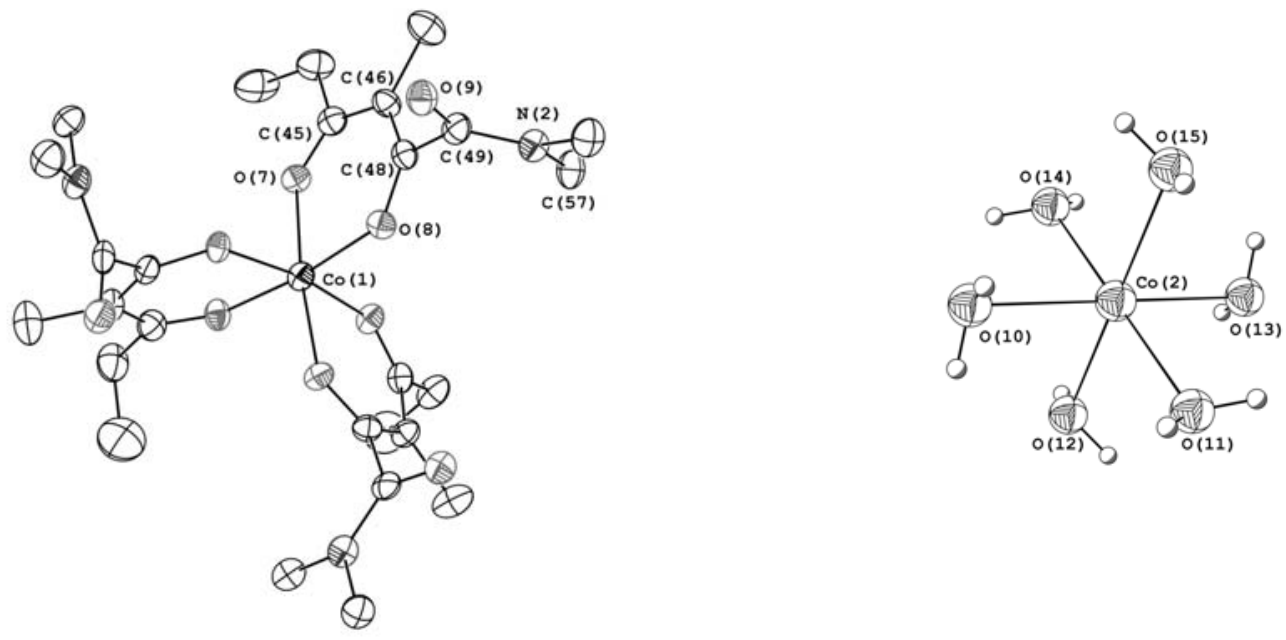

Figure 1. A, view of the complex 7, $\left[\left(\mathrm{C}_{21} \mathrm{H}_{22} \mathrm{NO}_{3}\right)_{3} \mathrm{Co}\right]_{2}-\mathrm{Co}\left(\mathrm{H}_{2} \mathrm{O}\right)_{6}$. The complex resides on a crystallographic inversion center at $1 / 2$, $1 / 2,1 / 2$ with $\mathrm{Co}\left(\mathrm{H}_{2} \mathrm{O}\right)_{6}$ at the center which bridges a pair of $\left(\mathrm{C}_{21} \mathrm{H}_{22} \mathrm{NO}_{3}\right)_{3} \mathrm{Co}$ complexes via O-H $\cdots \mathrm{O}$ hydrogen bonds (12). B, view of 7 showing a single Co-ligand assembly and the central $\mathrm{Co}\left(\mathrm{H}_{2} \mathrm{O}\right)_{6}$ with selected atoms labeled. Displacement ellipsoids are scaled to the $30 \%$ probability level. Hydrogen atoms and aromatic groups have been removed for clarity. Complex $\mathbf{7}$ crystallized with 1 molecule of benzene, which was removed from the image for clarity. 


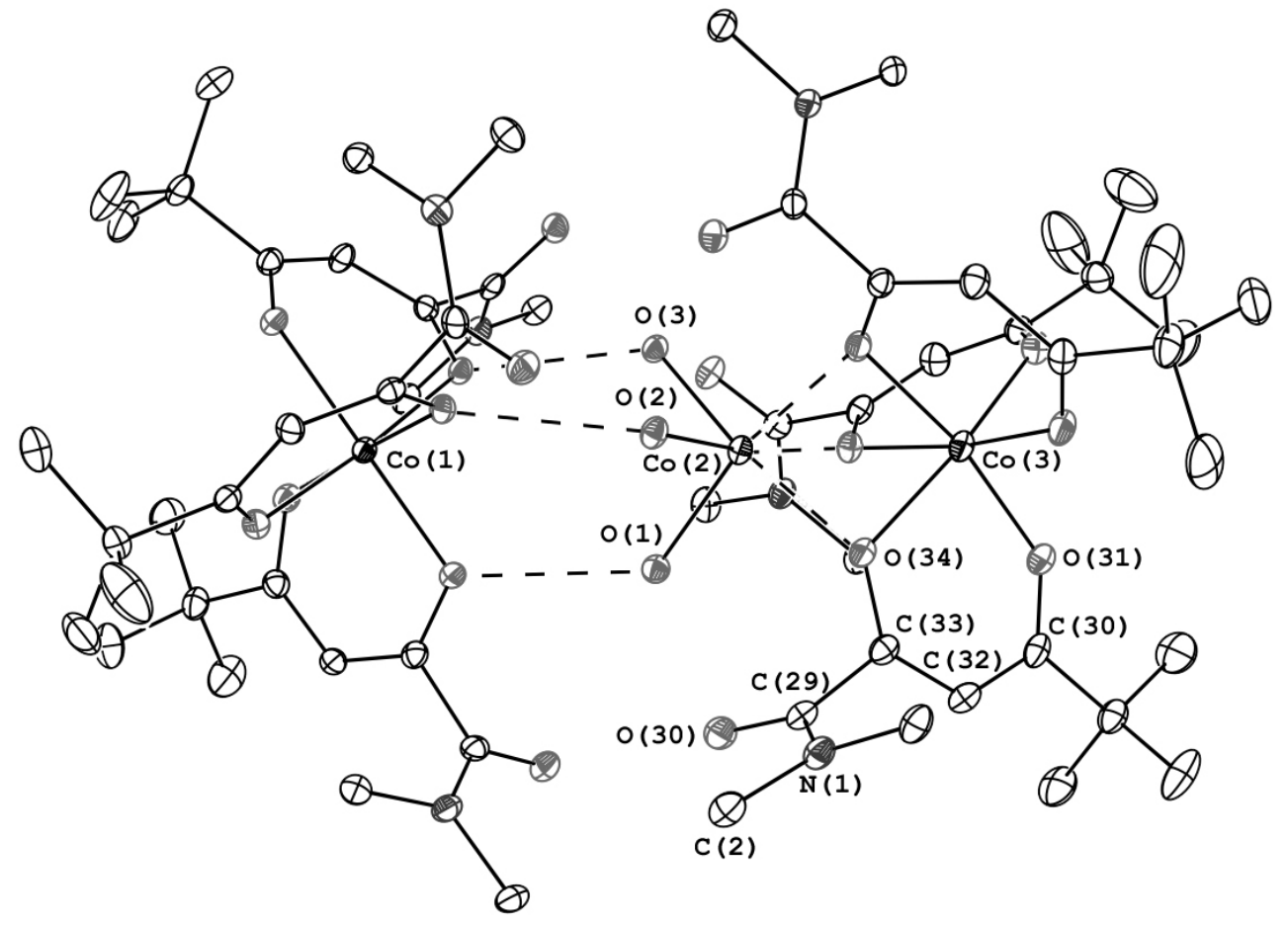

Figure 2. View of the $\mathrm{H}$-bound complex 3e $\left[\left(\mathrm{C}_{34} \mathrm{H}_{32} \mathrm{NO}_{3}\right)_{3} \mathrm{Co}\right]_{2}-\mathrm{Co}\left(\mathrm{H}_{2} \mathrm{O}\right)_{3}$ showing the labeling scheme for selected atoms (12). Displacement ellipsoids are scaled to the $30 \%$ probability level. Hydrogen atoms and the aromatic groups have been removed for clarity. The three water molecules of the bis Co complex are H-bound to carbonyl oxygen atoms of the adjacent mono Co complex. Complex 3e crystallized with 1 molecule of hexane, and two molecules of acetone, which were removed from the image for clarity.

Table 4. Selected bond lengths $[\AA]$ and angles $\left[{ }^{\circ}\right]$ for $3 \mathbf{e}$.

\begin{tabular}{llll}
\hline $\mathrm{Co}(3)-\mathrm{O}(31)$ & $2.058(2)$ & $\mathrm{C}(29)-\mathrm{O}(30)$ & $1.236(4)$ \\
$\mathrm{Co}(3)-\mathrm{O}(34)$ & $2.091(2)$ & $\mathrm{C}(29)-\mathrm{C}(30)$ & $1.515(4)$ \\
$\mathrm{C}(32 \mathrm{~d})-\mathrm{C}(33)$ & $1.407(4)$ & $\mathrm{N}(1)-\mathrm{C}(2)$ & $1.468(4)$ \\
$\mathrm{C}(30 \mathrm{~d})-\mathrm{C}(32)$ & $1.379(4)$ & $\mathrm{N}(1)-\mathrm{C}(29)$ & $1.349(4)$ \\
$\mathrm{C}(30 \mathrm{~d})-\mathrm{O}(31)$ & $1.285(3)$ & $\mathrm{C}(33)-\mathrm{O}(34)$ & $1.250(4)$ \\
$\mathrm{C}(33)-\mathrm{O}(34)-\mathrm{Co}(3)$ & $125.1(2)$ & $\mathrm{O}(34)-\mathrm{C}(33)-\mathrm{C}(32)$ & $123.4(3)$ \\
$\mathrm{C}(30)-\mathrm{O}(31)-\mathrm{Co}(3)$ & $120.78(9)$ & $\mathrm{O}(31)-\mathrm{C}(30)-\mathrm{C}(32)$ & $127.4(3)$ \\
$\mathrm{O}(31)-\mathrm{Co}(3)-\mathrm{O}(34)$ & $86.88(8)$ & $\mathrm{C}(30)-\mathrm{C}(32)-\mathrm{C}(33)$ & $125.8(3)$ \\
\hline
\end{tabular}

In both X-ray structures there are neutral donors, including water, surrounding the central cobalt atom. The reactions were run under an argon atmosphere using undried bulk solvents, and this was presumably the origin of the water. To determine if additional water would facilitate crystallization, several complexation reactions were simply performed open to air. Remarkably, the preparation of 3d under these conditions gave larger crystals that were easily obtained by filtration (instead of centrifugation); Importantly, no oxidation to $\mathrm{Co}(\mathrm{III})$ was observed under these conditions (TLC), whereas the analogous $\mathrm{Co}(\mathrm{acac})_{2}$ species oxidize more readily.

\section{Cobalt(III) structure}

Obtaining structural information about the $\mathrm{Co}$ (III) complexes (which are generated in situ for the Mukaiyama oxidation) might be more helpful in speculating about the nature of the active catalytic species. However, the Co(III) complexes are generally obtained as green oils or glasses. Efforts to grow crystals at $-20{ }^{\circ} \mathrm{C}$ were promising, but the resultant crystals were not of suitable quality for X-ray analysis. The $\mathrm{Co}$ (III) complexes are stable to flash chromatography on silica gel, and the complexes elute as numerous bands, some of which are readily separable while others are overlapping. We speculated one origin of these different bands to be diastereomeric complexation, and when separated the individual diastereomers might crystallize more easily. At room temperature individually eluted bands isomerize within a day or two to multiple species, as monitored by TLC. However, at $-20{ }^{\circ} \mathrm{C}$ the isomerization is slowed dramatically, and crystals suitable for X-ray crystallography were obtained from one of the more polar bands $\left(\mathrm{R}_{\mathrm{f}}=0.25,40 \%\right.$ EtOAc/hexanes $)$ of compound 9 (the oxidized version of 3d) (Figure 3). In this binuclear cluster the two central cobalt atoms are bridged by two hydroxyl groups, and each cobalt is surrounded by two chelating ligands. Significant bond lengths and angles have been summarized in Table 5 . 


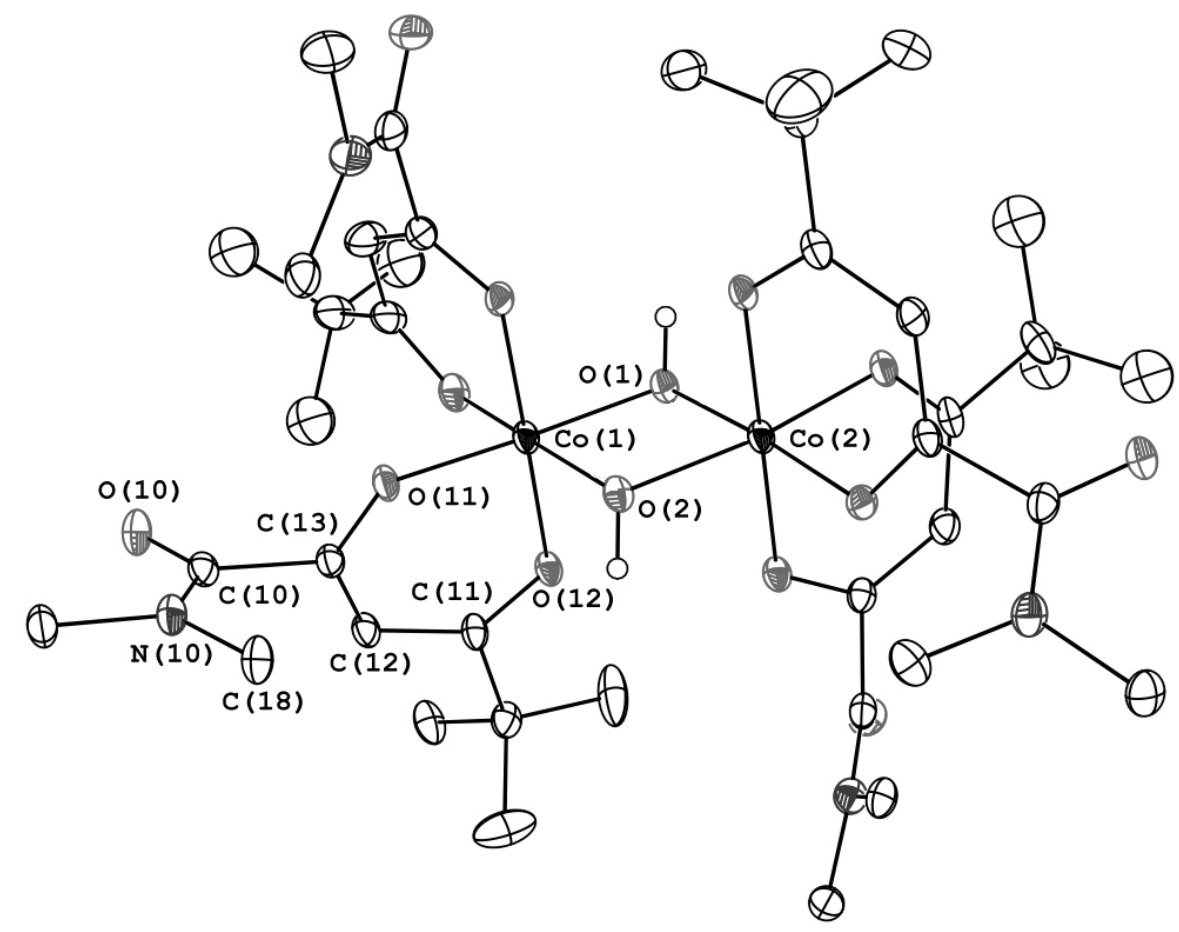

Figure 3. View of the complex $9\left[\left(\mathrm{C}_{34} \mathrm{H}_{32} \mathrm{NO}_{3}\right)_{3} \mathrm{Co}\right]_{2}(\mu-\mathrm{OH})_{2}$ showing the labeling scheme for selected atoms (12). Non-hydrogen atoms are represented by Gaussian ellipsoids at the 30\% probability level. Hydroxyl group hydrogen atoms are shown with arbitrarily small thermal parameters; all other hydrogens and aromatic groups have been removed for clarity. Two $t$-butyl groups were disordered, and modeled isotropically with $60 \%$ and $55 \%$ occupancy at the $t$-butyl groups centered at C44 and C24 respectively.

Table 5. Selected bond lengths $[\AA]$ and angles $\left[{ }^{\circ}\right]$ for $\mathbf{9}$.

\begin{tabular}{llll}
\hline $\mathrm{Co}(1)-\mathrm{O}(1)$ & $1.903(2)$ & $\mathrm{O}(11)-\mathrm{C}(11)$ & $1.284(4)$ \\
$\mathrm{Co}(1)-\mathrm{O}(2)$ & $1.904(2)$ & $\mathrm{O}(10)-\mathrm{C}(10)$ & $1.234(4)$ \\
$\mathrm{Co}(1)-\mathrm{O}(11)$ & $1.888(2)$ & $\mathrm{C}(12)-\mathrm{C}(13)$ & $1.415(4)$ \\
$\mathrm{Co}(1)-\mathrm{O}(12)$ & $1.887(2)$ & $\mathrm{C}(11)-\mathrm{C}(12)$ & $1.351(5)$ \\
$\mathrm{Co}(2)-\mathrm{O}(1)$ & $1.903(2)$ & $\mathrm{C}(10)-\mathrm{C}(11)$ & $1.541(4)$ \\
$\mathrm{Co}(2)-\mathrm{O}(2)$ & $1.918(2)$ & $\mathrm{N}(10)-\mathrm{C}(10)$ & $1.321(4)$ \\
$\mathrm{O}(12)-\mathrm{C}(13)$ & $1.254(4)$ & $\mathrm{N}(10)-\mathrm{C}(18)$ & $1.486(4)$ \\
$\mathrm{O}(1)-\mathrm{Co}(1)-\mathrm{O}(2)$ & $81.73(9)$ & $\mathrm{Co}(1)-\mathrm{O}(11)-\mathrm{C}(11)$ & $120.3(2)$ \\
$\mathrm{O}(1)-\mathrm{Co}(1)-\mathrm{O}(11)$ & $174.77(10)$ & $\mathrm{Co}(1)-\mathrm{O}(12)-\mathrm{C}(13)$ & $124.1(2)$ \\
$\mathrm{O}(1)-\mathrm{Co}(1)-\mathrm{O}(12)$ & $89.52(9)$ & $\mathrm{O}(12)-\mathrm{C}(13)-\mathrm{C}(12)$ & $124.6(3)$ \\
$\mathrm{Co}(1)-\mathrm{O}(1)-\mathrm{Co}(2)$ & $98.74(10)$ & $\mathrm{O}(11)-\mathrm{C}(11)-\mathrm{C}(12)$ & $128.9(3)$ \\
$\mathrm{Co}(1)-\mathrm{O}(2)-\mathrm{Co}(2)$ & $98.17(10)$ & $\mathrm{C}(11)-\mathrm{C}(12)-\mathrm{C}(13)$ & $122.4(3)$ \\
\hline
\end{tabular}

determine the structural differences between the active and inactive $\mathrm{Co}(\mathrm{III})$ complexes.

\section{Conclusions}

A modified synthesis for the preparation of $\mathrm{Co}(\mathrm{II})$ complexes bearing 2,4-dioxo-alkanoic acid dialkylamide ligands has been reported, and the resulting complexes are better precatalysts for the Mukaiyama oxidation compared to those prepared under aqueous alkaline conditions. X-ray structures for two of the $\mathrm{Co}$ (II) complexes have been solved, and they revealed a unique arrangement of cobalt atoms in the unit cell, where two anionic clusters each containing one $\mathrm{Co}$ (II) atom surrounded by three negatively charged dioxoamide ligands flank a central $\mathrm{Co}(\mathrm{II})$ atom with neutral donors. Oxidation of the $\mathrm{Co}(\mathrm{II})$ salts with $\mathrm{H}_{2} \mathrm{O}_{2}$ gave green oils or glasses. Separation of the slowly equilibrating mixtures by flash chromatography on silica gel resulted in the isolation of a single diastereomer that led to crystals of $\mathbf{9}$ suitable for X-ray analysis.

All of the new complexes reported in Table 2 possess some catalytic activity for the oxidation of $\gamma$-hydroxyl olefins to tetrahydrofurans. The complexes 3a and 3d have emerged as particularly useful catalysts, and the decision to employ one versus the other is influenced by product polarity and chromatographic characteristics. Crystals of $\mathbf{9}$ were dissolved in $i \mathrm{PrOH}$ and appeared as a single spot by TLC. These crystals successfully catalyzed the oxidation shown in Scheme 1 ( 1 atmosphere $\mathrm{O}_{2}, i \mathrm{PrOH}, 50{ }^{\circ} \mathrm{C}, 16 \mathrm{~h}$ ) in yields typically ranging from $70-90 \%$. Some spots isolated from the Co(III) species via chromatography were found to be inactive under standard Mukaiyama oxidation conditions. Investigations are currently underway to

\section{Acknowledgments}

We thank NSERC, donors of the Petroleum Research Fund and the DOD Prostate Cancer Research Program DAMD17-01-1-0109 for financial support. We also thank Professor Paul J. Ragogna and Jason Dutton for helpful discussions. 


\section{Insert Table of Contents artwork here}

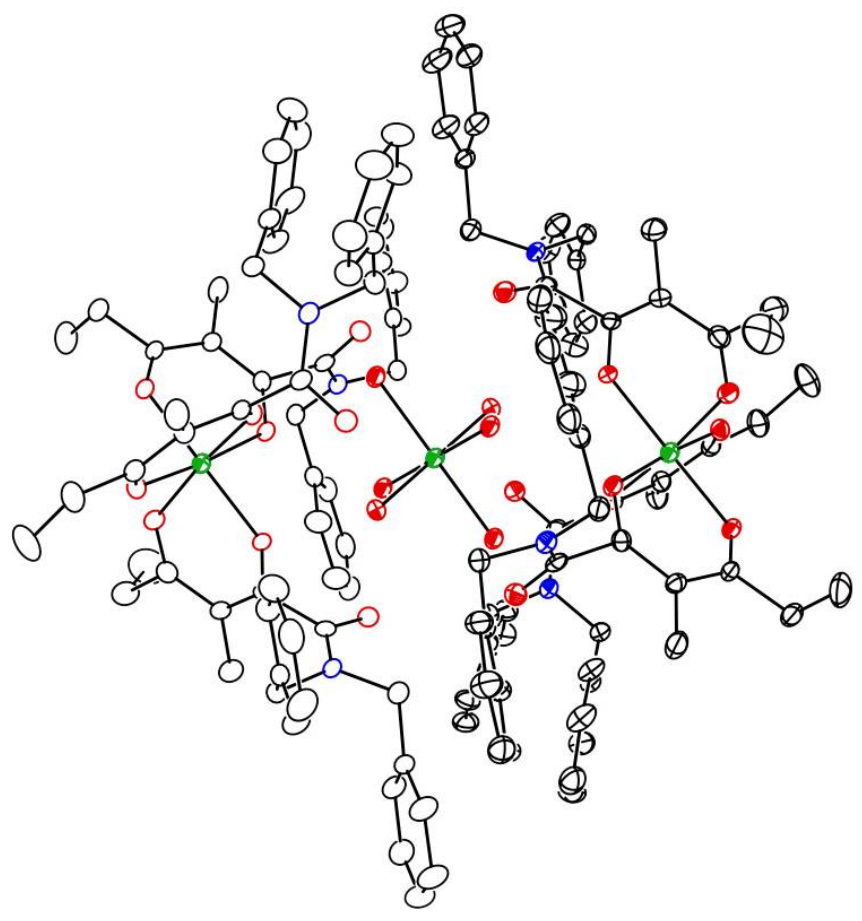

\section{References}

1. a) Inoki, S.; Kato, K.; Takai, T.; Isayama, S.; Yamada, T.; Mukaiyama, T. Chem. Lett. 1989, 18, 515-518; b) Mukaiyama, T.; Isayama, S.; Inoki, S.; Kato, K.; Yamada, T.; Takai, T. Chem. Lett. 1989, 18, 449-452.

2. Kato, K.; Yamada, T.; Takai, T.; Inoki, S.; Isayama, S. Bull. Chem. Soc. Jpn. 1990, 63, 179-186.

3. Isayama, S.; Mukaiyama, T. Chem. Lett. 1989, 573-576; Isayama, S. Bull. Chem. Soc. Jpn. 1990, 63, 1305-1310.

4. For examples of these catalysts being used in synthesis: a) Xu, X.-X.; Dong, H.-Q. J. Org. Chem. 1995, 60, 3039-3044; b) Tokuyasu, T.; Masuyama, A.; Nojima, M.; McCullough, K. J.; Kim, H.-S.; Wataya, Y. Tetrahedron 2001, 57, 59795989.

5. Mukaiyama, T. Aldrich Chimica Acta 1996, 29, 59-76.

6. a) Ioki, S.; Mukaiyama, T. Chem. Lett. 1990, 67-70; b) Wang, Z.-M.; Tian, S.-K.; Shi, M. Tetrahedron Lett. 1999, 40, 977-980; c) Tian, S.-K.; Wang, Z.-M.; Jiang, J.-K.; Shi, M. Tetrahedron Asymmetry 1999, 40, 551-2562.

7. Asimilobin: Wang, Z. M.; Tian, S. K.; Shi, M. Tetrahedron Lett. 1999, 40, 977-980. Gigantetrocin A: Wang, Z. M.; Tian, S. K.; Shi, M. Tetrahedron Asymmetry. 1999, 10, 667-670.

8. Mucocin: Takahashi, S.; Kubota, A.; Nakata, T. Angew. Chem., Int. Ed. 2002, 41, 4751-4754.

9. Mucocin: Evans, P. A.; Cui, J.; Gharpure, S. J.; Polosukhin, A.; Zhang, H. R. J. Am. Chem. Soc. 2003, 125, 1470214703.

10. Bullatacin: Zhao, H. D.; Gorman, J. S. T.; Pagenkopf, B. L. Org. Lett. 2006, 8, 4379-4382. Aplisiallene: Wang, J.; Pagenkopf, B. L. Org. Lett. 2007, 9, 3703-3706.

11. Mukoyama, M.; Isayama, S.; Kato, K.; Inoki, S.; Yamada, T.; Takai, T. Preparation of ketones by oxidation of olefins using cobalt diketone catalysts. Japanese Patent 02121944, 1990.

12. CCDC 203707 (7), 679940 (3e), 203708 (9) contains the supplementary crystallographic data for this paper. These data can be obtained, free of charge, via www.ccdc.cam.ac.uk/conts/retrieving.html (or from the Cambridge Crystallographic Data Centre, 12 Union Road, Cambridge CB2 1EZ, U.K. (Fax: 44-1223-336033 or e-mail: deposit@ccdc.cam.ac.uk)) 